\title{
Kontektualisasi Pemikiran Machiavelli tentang Kekuasaan-Tujuan Negara
}

\author{
Sri Hastuti Puspitasari
}

\begin{abstract}
As thinker who lived in renaissance atmosphere Machiavelly had put his empirical perspective into the end of state concept. In his book Prince he tended to focus on how to perpetuate power for the substance of a state of a kingdom was throne of a king. Today, eventhough military power has been used to strengthen a state, the idea of dictatorship would have been going to fade up. At this point, the end of state should be based upon political ethics and moral from this day forward.
\end{abstract}

\section{Pendahuluan}

Pada dasarnya pemikiran Nicolo merupakan persoalan penting dalam wacana negara.

Apabila berbicara tentang kekuasaan, mengandung gagasan kekuasaan, meskipun tidak terlalu lugas dalam menyatakan pentingnya gagasan konsep kekuasaan diretrospeksi. Bagi Machiavelii, berpikir terlalu teoritis tidaklah menarik. Pengalaman empirik kekuasaan di beberapa negara lebih menarik dalam pandangannya, sebagai seorang realis dan pikirannya berada pada atmosfir renaissance.

Walaupun gagasan Machiavelli tentang kekuasaan tidak berangkat dari konsep tertentu yang bersifat teoritis, tidak ada salahnya jika tanggapan terhadap pemikirannya dimulai dari menggagas konsep kekuasaan. Hal ini maka tidak dapat dilepaskan dari dimensi politik. Ketika berbicara kekuasaan dalam perspektif ilmu politik, maka akan ditemukan dua kubu. Kubu pertama menganggap bahwa kekuasaan sebagai masalah esensial dalam ilmu politik. Hal ini didasari oleh asumsi bahwa ada masalah yang lebih penting dan merupakan inti dari segala persoalan politik, yaitu negara. Kubu kedua mempunyai argumentasi bahwa kekuasaan adalah persoalan yang sangat substantif, esensial, bahkan merupakan hakikat ilmu politik. Negara hanya lembaga bagi kekuasaan.'

'A. Rahman Zainudin. 1992. Kekuasaan Negara, Pemikiran Politik Ibnu Khaldun. Jakarta: Gramedia Pustaka Utama. Negara sebagai kajian teoritik sempatmendominasi abad 20. Hlm. 1-3. 
Kekuasaan dalam beberapa konsep banyak dibedah dalam berbagai perspektif. Tetapi, ketika dihadapkan pada realita praksis, tuntutan yang muncul bahwa kekuasaan harus mengejawantahkan demokrasi (baca: ruang kebebasan bagi rakyat). Persoalan signifikan bukan pada apa kekuasaan yang demokratis, melainkan pada bagaimana mewujudkan kekuasaan yang demokratis.

Pemikiran Machiavelli tampaknya tidak menyinggung hal ini. Sebab, bagi Machiavelli, kekuasaan negara harus diwujudkan dengan adanya angkatan perang yang kuat dan tangguh, dan raja harus mewujudkannya untuk melindungi rakyat. Bagaimana distribusi kekuasaan raja, tidak terlalu penting, sebab di tangan raja segala keputusan berada. Oleh karena itu, kebebasan untuk berpartisipasi dalam mengontrol kekuasaan sangat terbatas.

\section{Terminologi Kekuasaan dalam Perspektif}

Bagi Machiavelli, kekuasaan raja merupakan sumber keabsahan kebijakankebijakan kerajaan atau negara. Tanpa kekuasaan kebijakan tidak mempunyai kekuatan untuk direalisasikan. Kekuasaan yang demikian adalah kekuasaan yang sah secara hukum. Jika kekuāsaan ditinjau dari sudut pandang aturan bernegara, kekuasaan harus mendapat legitimasi dari konstitusi sebagai hukum dasar bagi negara yang memuat kaidah-kaidah fundamental tentang sistem ketatanegaraan.

Machiavelli tidak secara tersurat menyatakan penggunaan konsep kekuasaan tertentu. Dengan demikian, tinjauan ulang terminologi kekuasaan dalam berbagai perspektif diperlukan untuk mendekatkan pemikiran Machiavelli pada konsep tertentu mengenai kekuasaan.

Pada dasarnya terminologi kekuasaan selalu terkait dengan hakikat, wewenang, dan dasar legitimasi. Hakikat kekuasaan bersentuhan dengan hal yang sebenarbenarnya. Dari segi hakikat, kekuasaan adalah kekuatan, kemampuan atau kesanggupan untuk berbuat sesuatu. Mengandung makna wewenang atas sesuatu pula. ${ }^{2}$ Dalam berbagai pemikiran, pengertian ini berkembang dan mempunyai heterogenitas persepsi sesuai dengan perspektif yang digunakan. Sebagai contoh, terminologi kekuasaan yang dianalisis dari perspektif filsafat ketuhanan akan berlainan dengan terminologi dari perspektif sosiologi.

Perspektif filsafat ketuhanan membedakan kekuasaan mutlak dan kekuasaan relatif atau nisbi. Kekuasaan mutlak hanya ada pada Allah. Adapun kekuasaan nisbi atau relatif ada pada manusia. Kemahakuasaan adalah kemestian bagi Allah. ${ }^{3}$ Allah adalah pemilik otoritas tertinggi atau pemilik dan pemegang tahta otoriter. Tahta Otoriter adalah tahta tertinggi dan secara hirarkhis di bawah tahta adalah

${ }^{2}$ Definisi kata-kuasa yang dirangkum dari Kamus Besar Bahasa Indonesia: Jakarta: Departemen Pendidikan dan Kebudayaan dan Balai:Pustaka. 1976. HIm. 528.

${ }^{3} H a m z a h$ Ya'cub. 1984. Filsafat Ketuhanan. Bandung: Al-Maarif. HIm. 169. 
tahta kekuasaan yang diberikan kepada para Nabi yang akan menjalankan kekuasaannya secara riil dalam masyarakat. ${ }^{4}$ Dalam perspektif ini, wewenang atau kekuatan untuk menguasai secara mutlak hanya milik Allah, penguasa atas alam makro kosmos dan alam mikro kosmos serta alam materi dan non materi. Kekuasaan yang diberikan kepada manusia adalah amanat yang berasal dari Tahta Otoriter. Manusia memerlukan institusi kekuasaan yang lebih konkrit dalam mengkoordinasi massa (umat) untuk mewujudkan tata kehidupan yang makmur, tertib dan adil. Kerangka pikir seperti ini diakui oleh hampir semua agama Samawi (Islam. Nasrani, Yahudi):

Sebuah gambaran dari perspektif agama, misalnya dalam tinjauan islam, Al Quran telah menggariskan bahwa Allah adalah pemilik segala kerajaan dan Maha Kuasa atas segala sesuatu. ${ }^{5}$ Allah menciptakan manusia dan menurunkan ke bumi dengan satu kekuasaan yang menyertainya yaitu sebagai khalifah yang akan memakmurkan bumi. ${ }^{6}$ Secara kelembagaan, Al-Quran juga menegaskan tiga prinsip pentaatan pada kekuasaan. Pertama, taat kepada Allah sebagai otoritas tertinggi. Kedua, taat kepada Rasulullah yang memegang tugas suci dari kekuasaan tertinggi dengan dasar wahyu yang diterima secara langsung. Ketiga, taat pada para ulil amri atau pemimpin yang telah mendapat kepercayaan untuk memimpin dengan adil sesuai dengan perintah kekuasaan pertama dan kedua. ${ }^{7}$ Oleh karena itu, kekuasaan dalam perspektif Islam adalah amanah dan mempunyai sifat metafisis, kosmopolit, dan universal, karena berlaku untuk alam semesta. Pertanggungjawabannya tidak hanya di dunia, tetapi berimplikasi di alam akherat.

Implementasi konsep kekuasaan dalam negara menurut hukum Islam didasarkan atas beberapa prinsip. Muhammad Taher Azhary mengemukakan bahwa praktek kekuasaan dalam Islam berada pada konsep negara hukum menurut prinsip-prinsip yang terdapat dalam Al-Quran dan Sunnah. ${ }^{8}$ Prinsip-prinsip tersebut adalah: Prinsip Kekuasaan sebagai Amanah, Prinsip Musyawarah, Prinsip Keadilan, Prinsip Persamaan, Prinsip Pengakuan dan Perlindungan terhadap Hak Asasi Manusia, Prinsip Peradilan Bebas, Prinsip Perdamaian, Prinsip Kesejahteraan, dan Prinsip Ketaatan Rakyat. Prinsip-prinsip ini memperoleh landasan nilai dári Al-Quran dan Hadist Nabi. Dengan demikian, praktek kekuasaan negara menurut Islam bersifat theologis. Namun, sifat theologis ini berbeda jauh dari praktek kekuasaan pada abad pertengahan yang juga mendasarkan pada nilai-nilai theologis, terutama dari ajaran Nasrani yang pada akhirnya melahirkan

${ }^{4}$ A. Rahman Zainudin. Loc. Cit.

SQS: Al-Malik: 1

¿QS: Al-Baqarah: 30

'QS: An-Nissa: 59

EMuhammad Tahir Azhary. 1992. Negara Hukum: Suatu Studi tentang Prinsip-Prinsipnya, Dilihat dari Segi Hukum Islam, Implementasinya pada Periode Negara Madinah dan Masa Kini. Jakarta: Bulan Bintang. 
theokrasi absolut. Pemikiran tentang kekuasaan negara yang bersifat theologis tersebut merekat pemahaman akan kekuasaan dari perspektif filsafat Ketuhanan.

Namun demikian, perspektif filsafat Ketuhanan terhadap kekuasaan ini banyak dikritik terlalu spekulatif kosmopolit, bahkan idealis dan utopis, sebab kurang menjangkau wilayah alam nyata. Namun, apapun penilaiannya jika berbicara mengenai hakikat kekuasaan, maka berbicara nilai esensial yang memberi "ruh" terhadap kekuasaan. Walaupun menolak untuk memberikan pandangan kekuasaan dari segi agama, Ibnu Khaldun tidak mengingkari bahwa agama dapat memberikan kekuatan kontrol terhadap kekuasaan dan justru unsur rabbani ini jangan sampai tertanggal dari dunia praktis kekuasaan agar tidak terjadi penyalahgunaan wewenang untuk keuntungan-keuntungan pribadi.s

Berbeda dengan Machiavelli, sebagai seorang penganut Kristen, ternyata ia memang tidak menyentuh dimensi ajaran Kristen tentang kekuasaan. Hal ini dapat dicermati melalui tulisannya dalam the Prince, yang banyak memberi nasehat bagaimana raja harus menjalankan keuasaan tanpa sedikitpun menyinggung ajaran Katolik yang melandasi kekuasaan, minimal nilai-nilai spiritualitas yang sebaiknya mengilhami moralitas kekuasaan. Sikap Machiavelli yang mengambil jarak dengan pengaruh gereja agaknya dapat dipahami, sebab ia menjadi saksi tentang bagaimana rusaknya negara-negara yang diperintah atas dasar legitimasi hukum Tuhan dengan gereja yang keberadaannya di atas negara.

Selain perspektif filsafat Ketuhanan yang dicontohkan ajaran Islam sebagaimana dipaparkan di atas, kekuasaan juga dianalisis dari perspektif sosiologis, yaitu melihat kekuasaan sebagai gejala empiris yang harus diamati di dalam masyarakat.

Titik tolak terminologi kekuasaan dalam perspektif sosiologis adalah rumusan Max Weber yang mengatakan bahwa dalam suatu hubungan sosial kekuasaan ialah kemampuan untuk melaksanakan kemauan sendiri, apapun dasar kemampuan ini, sekalipun mengalami perlawanan. D. Laswell dan Abraham Kaplan merumuskan kekuasaan sebagai suatu hubungan dimana seseorang atau sekelompok orang dapat menentukan tindakan seseorang atau kelompok orang lain agar sesuai dengan keinginan atau tujuan dari pihak yang menentukan. Sementara itu, van Doorn merumuskan kekuasaan sebagai suatu kemungkinan pembatasan tindakan bagi seseorang atau kelompok orang sesuai dengan apa yang ingin dicapai oleh pihak pertama yaitu penguasa. Rumusan van Doorn ini mendapat kritik, sebab kekuasaan tidak hanya membuka keinginan tindakan yang lebih besar dan leluasa. ${ }^{10}$

${ }^{9}$ A. Rahman Zainudin. Op.Cit. HIm 114, 135, 139, 164, 165. libnu Khaldun juga mengatakan bahwa peranan agama sàngat besar dalam mendirikan negara yang besar. la melihat besarnya peranan agama dalam mengadakan persatuan di kalangan rakyat melebihi faktor apapun di dunia.

${ }^{10}$ Mirian Budiarjo. Demokrasi di Indonesia, Demokrasi Parlementer dan Demokrasi Pancasila. jakarta: Gramedia. Hlm 92-93. 
Dari ketiga rumusan tersebut, dari segi substansi, kekuasaan tetap mengandung kemampuan atau wewenang. Pada rumusan Max Weber, : wewenang menyangkut pelaksanaan kemauan individu dalam kelompok. Dalam rumusan Laswell dan Abraham Kaplan seolah-oleh wewenang itu bersifat subordinatif, sebab ada kelompok yang menentukan dan yang ditentukan. Atau dalam interprestasi bebas, kelompok kedua (yang diperintah) menjadi tidak leluasa bertindak, karena dibatasi oleh tujuan yang hendak dicapai oleh pihak pertama. Jika wewenang itu bersifat subordinatif, maka gagasan Machiavelli bahwa seorang raja adalah kehendak utama dalam bertindak, dalam arti sebagai pusat dari segala keputusan, maka Machiavelli lebih melihat persoalan kekuasaan sebagai persoalan bagaimana raja sebagai seorang penguasa mempunyai wewenang berupa keharusan untuk mengatur sedemikian rupa rakyat yang dikuasainya. Secara singkat dapat dikatakan, bahwa Machiavelli, lebih melihat persoalan kekuasaan sebagai persoalan hubungan antara penguasa dengan yang dikuasai, dimana penguasa dipandang mempunyai kemampuan untuk memimpin negara dan mempunyai, wewenang untuk mengatur negara.
Kekuasaan juga diartikan sebagai dominasi dan pengawasan. Barrington Moore memberikan definisi yang berorientasi pada metode atau cara bagaimana golongangolongan atau individu-individu tertentu berhasil melakukan dominasi terhadap sesamanya. Adapun Talcott Parsons dan Robert Lync cenderung merumuskan kekuasaan sebagai kekuatan untuk mengawasi atau melakukan pengawasan. Parsons menganggap kekuasaan sebagai pemilihan fasilitas-fasilitas untuk menguasai. Sedangkan Robert Lync menganggap kekuasaan sebagai sumber sosial yang utama untuk mengadakan pengawasan:"

Meskipun berbau sosialis, barangkali ada benarnya penyataan Frederich Engels bahwa keuasaan itu sesuatu yang berasal dari masyarakat dan berkuasa di atas masyarakat. Dari rumusan itu, ternyata kekuasaan dapat ditarik pada pengertian yang lebih umum, yaitu sebagai suatu kesempatan bagi seseorang atau sekelompok orang untuk mewujudkan kehendaknya dalam bentuk suatu aksi sosial bagi mereka yang menentang kehendak maupun tidak. ${ }^{12}$

Dari segi substansi kekuasaan, pemikiran Machiavelli lebih dekat pada tataran konsep dari Parsons, dimana kekuasaan mengandung unsur pengawasan. Bagi Machiavelli,

"Miriam Budiarjo. 1991. Aneka Pemikiran tentang Kekuasaan dan Wibawa. Jakarta: Pustaka S:nar Harapan. HIm. 31.

¿Anthony Giddens dan David Held. Pendekatan Klasik dan Kontemporer mengenai Kelompok Kekuasaan dan Konflik. Jakarta: Rajawali Press. HIm. 21, 23. 
kekuasaan yang ada pada raja pada akhirnya harus menjelmakan kekuasaan untuk mengawasi tindakan para menterimenterinya, ${ }^{13}$ bangsawan, ${ }^{14}$ angkatan perang, ${ }^{15}$ dan rakyat. ${ }^{16}$

Sebenarnya kekuasaan dalam perspektif sosiologis ini mempunyai landasan asas kedaulatan rakyat atau rakyat dianggap sebagai suatu supremasi dalam struktur kekuasaan yang legal. Tetapi ketika kekuasaan itu dilembagakan, maka rakyat menjadi komunitas yang dikuasai oleh kebijakan-kebijakan penguasa. Rakyat harus dibatasi geraknya dalam sistem aturan main yang dibuat penguasa. Karena itu terjadi dominasi. Dalam segala jenis dan skala organisasi apapun, struktur kekuasaan yang dominatif selalu ada. Kekuasaan dalam terminologi sosial ini timbul karena adanya interaksi sosial, dimana dalam interaksi sosial para pihak tidak selalu berada pada posisi egaliter.

Dari perspektif sosiologis ini, pada dasarnya hakikat atau substansi kekuasaan relatif tidak berbeda dengan perspektif filsafat Ketuhanan, sebab sama-sama mengarah pada kemampuan, kekuatan dan wewenang. Perbedaannya terletak pada basis nilai yang melandasi adanya kekuasaan. Nilai religius dominan dalam filsafat Ketuhanan. bahkan menjadi basis nilai yang melandasi kekuasaan. Sedangkan nilai-nilai sosial

${ }^{13}$ Machiavelli berpendapat bahwa ada suatu cara bagi raja untuk mengetahui kinerja menterinya, yaitu jika menteri lebih memikirkan dan mau mencari untung untuk diri sendiri dibandingkan dengan. kepentingan raja, maka dia bukan menteri yang baik dan raja tidak perlu mempercayainya. Untuk membuat menteri setia, raja harus memikirkannya, memberi kehormatan dan kekayaan serta membuat menteri selalu merasa berutang pada raja. Kunci dari semua itu adalah kepercayaan. Raja harus memilih orang-orang yang bijaksana untuk menguasai pemerintahan. Tetapi raja harus teliti, sebab pada akhirnya rajalah yang mengambil keputusan. Raja dapat menerima maupun menolak nasehat yang diberikan padanya.

"Machiavelli membahas kekuasaan institusional. la memfokuskan pada kekuasaan yang diperoleh karena jasa baik terhadap rakyat. Rakyat memberi dukungan penuh terhadap orang biasa karena kemampuannya menjadi penguasa, namun ada segolongan bagsawan yang harus disikapi hati-hati. Pertama, memanfaatkan bangsawan untuk memberi nasihat yang sehat sehingga mereka merasa dihormati; Kedua. jika bangsawan memilih independen. maka penguasa harus menjaga ambisi pribadi para bangsawan. Penguasa yang didukung rakyat harus tetap mempertahankan persahabatan, karena yang dibutuhkan rakyat adalah kehidupan tanpa penindasan.

is Dasar setiap negara adalah adanyạ hukum dan pasukan yang baik untuk mempertahankan negaranya. Militer harus merupakan organisasi yang didukung oleh pasukannya sendiri yang terdiri dari rakyat atau warga negara atau orang-orang yang dikuasainya. Pasukan bayaran, bantuan, dan gabungan merupakan pasukan yang membahayakan raja. Raja hendaknya mempelajari perang dan organisasi sebagai seni yang dibutuhkan seorang pemimpin.

${ }^{16}$ Raja harus bertindak untuk tetap disegani rakyat, dengan menunjukkan kemampuan pribadi dan keahliannya dalam berperang dan memimpin pasukan; penghargaan terhadap bakat seseorang, dan mendorong rakyat melakukan tugas dengan rasa tenang, tanpa rasa takut, serta menghargai orang yang ikut memakmurkan negara. 
dianggap lebih rasional menjadi acuan utama bagi mereka yang melihat kekuasaan sebagai fenomena sosial yang tidak terelakkan.

Jika dilihat dari substansi kekuasaan, pikiran Machiavelli dapat masuk dalam tataran kedua perspektif ini. Tetapi dari segi basis nilai pikiran Machiavelli terasa sulit untuk dikategorikan. Di satu pihak, ia mengambil jarak dengan perspektif religius dalam memandang soal-soal yang berbau duniawi. Di pihak lain, ia mengkonsentrasikan perhatian pada bagaimana raja sebagai penguasa harus bersikap dan bertindak dalam menjalankan kekuasaan. Baginya, dengan adanya angkatan perang yang kuat, maka menjadi jaminan bagi keamanan dan kokohnya negara. la seolah menekankan adanya negara penjaga malam yang hanya menjalankan fungsi ketertiban tanpa melibatkan secara penuh masyarakat yang ada didalamnya. la tampaknya berpikir bahwa tanggung jawab untuk membuat ketertiban sepenuhnya ada pada seorang raja:Untuk itu, raja harus membuat rakyat selalu takut, taat dan bergantung padanya. Pengabaian perspektif religius dan sosiologis oleh Machiavelli ini membuat ketidakjelasan mengenai perspektif mana yang digunakan Machiavelli dalam memberi kontribusi pemikiran kepada Raja Lorenzo De Medici.

\section{Dasar Legitimasi Kekuasaan}

Apabila secara hakikat antara kekuasaan dalam tinjauan filsafat Ketuhanan sebagai gejala sosial tidak menampakkan perbedaan yang mencolok, maka dari segi dasar legitimasinya sangat berbeda. Perspektif
Ketuhanan dasar legitimasinya adalah Tuhan melalui perintah-perintah dalam kitab suci. Dengan demikian, sumber legitimasi kekuasaan dalam perspektif ini berasal dari kekuatan supranatural, yaitu Tuhan. Sedangkan perspektif sosiologis dasar legitimasinya berasal dari masyarakat. Apabila kekuasaan adalah fenomena yang alami, maka masyakarat melalui interaksi akan menghimpun suatu kekuatan dan selanjutnya secara institusional kekuasaan dipercayakan kepada pimpinan atau sekelompok orang untuk melaksanakan.

Pengalaman di negara-negara Eropa Barat terutam pada akhir abad pertengahan, legitimasi atas dasar kekuasaan Tuhan mendapat banyak kritikan, sebab para penguasa pada waktu itu justru memonopoli kekuasaan atas dalih sebagai wakil Tuhan, sehingga tidak seorangpun mempunyai wewenang untuk menilai.

Legitimasi atas dasar nilai religius yang berasal dari kekuatan Illahi ini membawa implikasi bahwa kekuasaannya berada di atas penilaian moral. Penguasa adalah sesuatu yang menggerakkan bukan sebagai subjek penanggungjawab. Masyarakat tidak dapat bertindak lain kecuali menerima titah penguasa. Thomas Aquinas (1255-1274) menggantungkan legitimasi kekuasaan negara pada kesesuaiannya dengan tuntutantuntutan normatif. Thomas Aquinas menegaskan bahwa hukum kodrat harus menjadi dasar kekuasaan, bukan kekuasaan yang menjadi dasar hukum. la menuntut adanya penggunaan kekuasaan atas dasar legitimasi etis. ${ }^{7}$

\footnotetext{
"Fran Magnis Suseno. 1986. Kuasa dan Moral. Jakarta: Gramedia. HIm. 1. 4, 5.
} 
Dengan demikian, pengabsahan atau legitimasi kekuasaan atas dasar religius ini bersifat perenial atau :abadi. Implikasi negatifnya adalah apabila penguasa tidak dapat mengendalikan ego pribadinya sebagai manusia, sehingga muncul kecenderungan seperti yang dikemukakan oleh Lord Acton bahwa kekuasaan itu cenderung absolut. Bagaimanapun kekuasaan manusia mempunyai banyak kelemahan, kecuali manusia itu merupakan makhluk par excellence seperti Nabi yang menerima legitimasi tahta kekuasaan atas dasar wahyu yang diterimanya secara langsung dari Tuhan sebagai pemegang tahta legitimasi tertinggi. Kekuasaan atas dasar wahyu tersebut digunakan untuk mewujudkan kehidupan yang lebih baik bagi umat.

Kekuasaan atas dasar legitimasi Tuhan terutama di Eropa pada abad pertengahan, memberikan preseden bahwa kekuasaan yang mempunyai legitimasi seperti itu ternyata tidak menjamin adanya keadilan bagi rakyat. Hal ini yang dilihat dan dirasakan Machiavelli sehingga la menentang penggunaan kekuasaan atas dasar legitimasi lembaga religius ketika itu.

Pudarnya dominasi lembaga religius dalam politik praktis mendorong munculnya pemikiran agar kekuasaan itu mempunyai dasar legitimasi yang dapat diterima secara rasional. Kemudian muncul suatu pemikiran bahwa dasar kekuasaan itu adalah rakyat atau masyarakat.

Legitimasi dalam perspektif masyarakat ini sebagaimana dikatakan oleh David Easton adalah keyakinan bahwa untuk menerima dan mentaati penguasa dan memenuhi tuntutantuntutan dari rezim itu merupakan sesuatu yang wajar: A.M. Lipest menegaskan bahwa cakupan legitimasi ini meliputi kemampuan untuk membentuk dan mempertahankan kepercayaan bahwa adanya lembagalembaga politik adalah sesuatu yang wajar untuk masyarakat. ${ }^{18}$

Jika konsep legitimasi ini dianggap sebagai suatu keyakinan dan keyakinan itu didelegasikan dalam bentuk kekuasaan, maka sebenarnya ada hal yang lebih dalam atau imanen dari keyakinan, yaitu nilai yang melandasi adanya keyakinan àtau kepercayaan itu. Mengapa masyarakat begitu yakin bahwa penguasa yang ada dipercaya melaksanakan kekuasaan? Hal ini barangkali sukar dijelaskan secara logika. Sebab, sifatnya yang imanen (terselubung) dalam hati nurani rakyat. Sedangkan dimensi transedensi keyakinan adalah kekuasaan yang dilaksanakan berdasarkan legitimasi tidak hanya menyangkut keyakinan untuk menerima dan mentaati penguasa serta meliputi kemampuan membentuk, mempertahankan kepercayaan terhadap lembaga-lembaga kekuasaan semat. Lebih dari itu, legitimasi menyangkut tentang keyakinan, yaitu nilai kebenaran dan keadilan yang menggerakkan keyakinan pada hati nurani. Oleh karena itu nilai dapat menjadi kontrol bagi kekuasaan, minimal kontrol moral.

Kontrol moral inilah yang tampak oleh Machiavelli, karena ia memberi begitu banyak hak tentang bagaimana seorang raja

${ }^{18}$ Lihat pendapat David Easton dan A.M. dikutip oleh Mirian Bidiarjo. Op.Cit. HIm 90-91. 
memerintah, tetapi tidak memberi keterangan tentang apa atau siapa yang harus memberi - kontrol moral terhadap raja. Aspek moralitas inilah yang tidak dikedepankan oleh Machiavelli, sehingga pemikirannya sering dicap tidak moralis.

Bagi Machiavelli, legitimasi moral bukanlah hal yang utama, sebab kestabilan dan kelestarian kekuasaan lebih penting. la memang melawan arus pemikiran yang berkembang ketika itu. Machiavelli menganut semacam sinisme moral dalam filsafat politik dan dengan berani ia menuangkan gagasannya bahwa tujuan berpolitik bagi penguasa adalah mengamankan kekuasaan yang ada di tangannya. ${ }^{19}$

Jika kita membuat perbandingan dengan pemikiran politik Islam, Ibnu Khaldun menolak legitimasi religius dan kekuasaan. Tetapi Ibnu Khaldun pernah mengungkapkan bahwa penolakannya untuk memandang kekuasaan dari tinjauan religius bukan berarti ia mengabaikan peran agama sama sekali. Agama merupakan faktor penting untuk membimbing dan menuntun manusia dari sifat-sifat "kebinatangan". Dalam hubungan kekuasaan dan moralitas, agama sebagai unsur rabbani dapat menjadi kontrol agar manusia lebih dekat kepada kebaikan dan prinsip-prinsip keadilan..$^{20}$

Respon yang muncul terhadap dua paradigma legitimasi itu yaitu legitimasi religius dan legitimasi masyarakat melahirkan penilaian tajam bahwa legitimasi religius cenderung memberikan status Quo bagi penguasa. Machiavelli tampaknya berada pada wilayah ini. la begitu apatis terhadap institusi moral yang mengatasi persoalan negara. Hal ini sesuai dengan alam pikiran Renaissance yang menghilangkan segala hal yang bersifat transedental, metafisi, karena dianggap tidak rasional termasuk memisahkan agama dan negara. Agama dalam pandangan Machiavelli dianggap sebagai institusi moral. Sebaliknya kritik yang ditujukan kepada legitimasi masyarakat adalah sekularisasi dalam kekuasaan, sehingga kekuasaan jauh dari keberpihakan terhadap kebenaran dan keadilan yang harus ditegakkan di muka bumi. Legitimasi pertama seolah-olah hanya mendasarkan pada pendekatan intuitif. Sebaliknya legitimasi kedua menekankan pada pendekatan rasional. Dalam hal ini, sikap Machiavelli tidak terlalu jelas, sebab ia tidak begitu peduli apakah legitimasi kekuasaan raja berasal dari masyarakat atau bukan. Baginya, karena raja sudah memegang kekuasaan, maka ia harus mempertahankannya.

Jika menerapkan metode dialektika, legitimasi religius sebagai tesis dan legitimasi masyarakat sebagai antitesis, maka keduanya dapat dipertemukan dengan pernyataan bahwa kekuasaan selain memiliki dimensi legitimasi intuitif atau keyakinan keimanan. juga memiliki dimensi rasional. Tetapi kecenderungan yang besar terjadi pada dominannya pendekatan rasional terhadap kekuasaan, sebab kekuasaan adalah hal yang empirik dan dapat dikontrol oleh masyarakat

${ }^{19}$ M. Sastrapratedja dan Franz M. Parera. Sang Penguasa, Surat-surat Kenegaraan untuk Umat Lorenzo De Medici. Jakarta: Gramedia.HIm xxx-xxxi.

${ }^{20} \mathrm{~A}$ Rahman Zainudin. Op. Cit. HIm 114, 135, 140. 
secara nyata melalui cara yang logis. Dari segi legitimasi ini pikiran. Machiavelli makin tampak tidak berangkat dari legitimasi religius. Barangkali ia. agak condong pada legitimasi masyarakat seperti yang dapat kita lihat pada pikirannya tentang kekuasaan yang konstitusional, yaitu kekuasaan yang mendapat dukungan penuh dari rakyat. Dukungan penuh ini mengandung aspek keyakinan yang pada akhirnya melahirkan legitimasi.

\section{Retrospeksi atas Hakikat dan Tujuan Negara}

Pemikiran Machiavelli dalam the Prince pada dasarnya mengajak kita untuk memikirkan kembali apa sebenarnya hakikat dan tujuan negara. Pada hakikatnya negara adalah suatu organisasi masyarakat, yaitu sekelompok orang yang dengan kerjasama dan pembagian tugas yang jelas mengejar suatu tujuan bersama yang tidak dapat dicapai orang masing-masing, karena di luar kemampuannya sendiri. Kerjasama demi tercapainya tujuan bersama serupa itu dijamin: Pertama; Dengan adanya pembagian tugas yang jelas dan terarah pada tujuan bersama; Kedua, dengan adanya pimpinan dan pengawasan. Dengan menggunakan pembagian tugas itu, maka setiap anggota mempunyai tugas tertentu dalam hubungan dengan keseluruhan. Tugas itu biasa disebut fungsi. Selain itu, setiap organisasi mempunyai pucuk pimpinan yang diserahkan kepada petugas atau lembaga tertinggi. Tugas utamanya ialah mengatur dan menjaga agar organisasi dengan bagian-bagiannya mengejar tujuan bersama dengan cara yang tepat dan efektif. Untuk bagian-bagian organisasi, fungsi-fungsi pimpinan dan pengawasan itu dapat dan biasanya juga harus diserahkan kepada petugas-petugas atau pemimpin-pemimpin bawahan. ${ }^{21}$

Berbeda dengan organisasi-organisasi masyarakat itu, negara adalah suatu organisasi masyarakat yang berdaulat. Berdasarkan kedaulatannya ini negara dapat menentukan bahwa semua orang yang mendiami wilayahnya, kecuali orang asing, adalah warganya yang harus tunduk padanya. Orang-orang tidak ditanya lebih dahulu, tetapi secara otomatis adalah warga negara dengan hak-hak dan kewajiban-kewajiban. Demikian pula anak-anak yang lahir dari mereka. Berdasarkan kedaulatannya itu pula negara dapat menetapkan peraturan perundangundangan yang bersifat memaksa mengenai tingkah laku warganya dan harus dipatuhi di bawah ancaman hukuman bagi pelanggarpelanggarnya. Selain itu, negara mempunyai hak untuk menuntut kepada para warganya agar menyerahkan sebagian kekayaan dan pendapatan kepadanya, antara lain sebagai pajak, atau melakukan sesuatu untuknya seperti membela tanah air terhadap serangan musuh dari luar. Mengenai persoalan moral dalam negara, seharusnya negara dikeluarkan dari persoalan-persoalan moral. ${ }^{22}$

${ }^{21}$ J.H.A. Logeman dalam Kirdi Dipoyudo. 1989. Tugas Pokok Negara dalam Memajukan Kesejahteraan Sosial. Analisis CSIS. hIm 539.

${ }^{22}$ F. Isjwara. 1987. Pengantar Ilmu Politik. Bandung. hlm 58, 99-108. 
Kedaulatan yang merupakan ciri utama negara itu bersumber pada tujuan negara sebagai masyarakat yang paling lengkap dan paling tinggi. Tanpa kedaulatan; negara.tidak akan dapat mencapai tujuannya, yang juga lebih luas dan lebih lengkap daripada tujuan masyarakat lain. Justru karena lain-lain masyarakat itu tidak mencukupi kebutuhan manusia sepenuhnya, maka negara dibentuk. Kepentingan-kepentingan yang menjadi urusan negara mengatasi kemampuan masyarakat itu.

Di antara kepetingan-kepentingan itu yang dirasakan sebagai kepentingan utama adalah keamanan diri dan harta benda orang-orang terhadap bahaya dari luar. Dengan adanya ancaman itu orang-orang bersatu menjadi kesatuan menetap untuk menangkisnya. Dengan demikian, dibentuk organisasi masyarakat yang bertugas untuk memperhatikan kepentingan itu. Agar dapat menjalankan tugasnya dengan baik, organisasi itu diberi kekuasaan untuk membuat peraturan-peraturan yang harus dipatuhi oleh seluruh masyarakat dan mengambil tindakantindakan yang perlu. Timbullah suatu kekuasaan yang dapat menciptakan dan membina tata tertib serta menjaga keamanan. Kekuasaan itu diberikan kepada seorang atau sekelompok orang yang menonjol dalam kebijaksanaan, kecakapan dan keberanian. Setiap orang tunduk padanya dan yang tidak mau dapat dipaksa dengan kekerasan untuk taat kepadanya. Pada permulaan peradaban organisasi kekuasaan itu bersifat sederhana dan belum begitu besar. Tetapi dengan kekuasaan umum yang dimaksud untuk menyusun dan menjaga tertib dalam masyarakat itu muncul suatu bentuk baru kehidupan bersama, yaitu negara. Dengan perkembangan organisasi kekuasaan dan tugasnya, berkembang pula negara. Dewasa ini negara merupakan suatu organisasi yang sangat kompleks dan mempunyai berbagai segi. ${ }^{23}$

Dari uraian di atas jelaslah bahwa negara bukanlah tujuan, melainkan untuk mencapai suatu tujuan. Sesuai dengan hal tersebut, pemimpin-pemimpin menganggap negara sebagai suatu jembatan yang menghubungkan kita dengan masa depan yang lebih baik. Ada juga yang menyamakannya dengan sebuah bahtera yang menyangkut seluruh rakyat ke pelabuhan kesejahteraan. Pada hakikatnya negara adalah suatu lembaga sosial yang dibentuk oleh orang-orang untuk memenuhi kebutuhan-kebutuhan vital mereka yang tidak dapat dipenuhi dengan jalan lain. Negara adalah suatu keharusan dalam arti bahwa pada tahap perkembangan tertentu, orangorang harus membentuk negara. Dengan demikian, mutu suatu negara bergantung pada kemampuannya untuk memenuhi kebutuhan-kebutuhan rakyat dengan baik.

Kirdi Dipoyudo mengatakan bahwa tujuan negara merupakan masalah utama bagi para negarawan dan ahli politik sejak zaman kuno. Plato dalam karyanya tentang negara timbul karena kebutuhan orang-orang. Tiada seorang pun dapat memenuhi kebutuhannya sendiri. Untuk memenuhi kebutuhannya yang tidak dapat dipenuhi oleh masing-masing orang, disusunlah negara. Demikian pula untuk

${ }^{23}$ J.D. Mabbot dan Ernst B. Shultz dalam Kirdi Dipoyudo, op.cit., hlm. 540. 
menyelenggarakan hidup yang baik ${ }^{24}$ bagi semua warganya.

Pendapat Plato dan Aristoteles tentang negara dan tujuannya itu sudah menjadi pendapat umum. Semua negara yang pernah ada, yang masih ada dan yang. akan ada di masa mendatang adalah untuk mencapai tujuan tersebut. Tujuan negara pada intinya sama, dahulu, sekarang dan di masa yang akan datang. Tujuan negara ialah kesejahteraan umum (bonun commune atau common welfare), yaitu kesejahteraan manusiawi yang lengkap bagi setiap dan semua warga negara. Negara dibentuk untuk menjamin kesejahteraan lahir batin semua warganya sebagai suatu keseluruhan. Itulah tujuan negara dan alasan adanya negara. Negara ada untuk mengabdi kepada kepentingan rakyat. Tetapi hal ini bukan suatu alasan untuk mengambil seluruh kekuasaan rakyat. Negara hanya membantu orang-orang yang tidak dapat memenuhi kebutuhankebutuhannya secara wajar. Oleh karena itu, dalam negara ada asas yang harus dipegang teguh, yaitu sesuatu yang dapat dikerjakan oleh orang-orang atau masyarakat yang lebih kecil tidak boleh diambil oleh kelompok yang lebih besar atau lebih tinggi. ${ }^{25}$

Dimanakah pemikiran Machiavelli dalam hubungannya dengan hakikat dan tujuan negara? Jika mencermati secara kritis bahwa hakikat negara adalah adanya kemauan rakyat, maka akan melihat benang merah pemikiran Machiavelli dalam tatanan bagaimana raja harus senantiasa membuat rakyat merasa berutang budi padanya, dan sejauh mungkin menghindari adanya penindasan dan rasa bertanggungjawab atas semua itu. Tetapi, siapa yang dapat menjamin bahwa raja tidak akan sewenang-wenang dalam mewujudkan harapan rakyatnya itu? Machiavelli memberikan jawab: Hukum. Tetapi hukum yang bagaimana, Machiavelli tidak memberi gambaran, dan inilah kelemahan pemikirannya. Machiavelli lebih banyak memfokuskan diri para teknik dan taktik mempertahankan kekuasaan, sehingga hakikat negara bagi Machiavelli bukan kehendak rakyat, tetapi kehendak raja 'untuk mempertahankan kekuasaannya.: Dengan demikian, tujuan yang ingin dicapai dengan adanya negara bukan bermuara pada kesejahteraan rakyat, sebab pandangannya tidak berangkat dari adanya, hakikat negara tidak lebih dan tidak kurang adalah tata tertib, keamanan, dan ketenteraman. Tanggung jawab itu sepenuhnya ada di tangan seorang raja yang mampu mengorganisasi negara dengan dukungan pasukan perang yang kuat. Untuk mempertahankan kekuasaan yang ada pada raja, raja harus membuat rakyat senantiasa tunduk padanya. Negara besar dan kekuasaan rakyat yang mengecil pada akhirnya tidak akan melahirkan kekuasaan masyarakat, sehingga yang dapat memperbaiki negara sekiranya kekuasaan yang besar. ${ }^{26}$

\footnotetext{
${ }^{24}$ Hidup yang baik artinya adanya keamanan dari bahaya-bahaya yang mengancam orang-orang dan kebebasan dari kekurangan-kekurangan fisik, juga tersedianya sarana-sarana yang berlimpah-limpah untuk mewujudkan kesejahteraan materiil dan spirituil, termasuk kehidupan intelektual dan susila.

${ }^{25}$ Kirdi Dipoyudo, op.cit, hlm 540-541.

${ }^{26}$ Arief Budiman. 1996. Teori Negara, Negara, Kekuasaan dan Ideologi. Gramedia. Jakarta. hlm 24.
} 
Ide-ide Machiavelli tentang pengamanan terhadap kekuasaan dengan instrumen utama kekuatan militer patut dikhawatirkan. Hal ini menyebabkan destruksi kekuasaan yang lebih besar. Jika instrumen kekuatan militer ini menjadi andalan utama negara dalam mempertahankan kekuasaan, maka apapun yang dianggap dapat mengancam kekuasaan dari manapun datangnya merupakan musuh yang harus berhadapan dengan kekuatan represif militer. Walaupun Machiavellimelihatnya dari konteks kekuatan defensif negara terhadap serangan dari luar, tetapi besar kemungkinan hal itu juga berlaku bagi penindakan terhadap rakyat yang dianggap musuh, karena mengobarkan perlawanan terhadap kekuasaan. Dengan demikian, kekuasaan negara akan dieksploitasi untuk mengamankan kekuasaan seorang yang sedang berkuasa, bukan untuk membela ketertindasan rakyat. Oleh karena itu, tujuan negara menjadi terfokus pada bagaimana mempertahankan kekuasaan yang sudah ada di tangan, apapun caranya.

Jika hal itu terjadi, maka negara dapat memaksakan kehendaknya kepada warga atau kelompok yang ada di masyarakat. Bahkan, jika perlu. negara mewakili keabsahan menggunakan kekerasan fisik dalam memaksakan kepatuhan masyarakat terhadap perintah-perintah yang dikeluarkan. Negara sebagai kelembagaan menghadirkan keamanan di tengah kehidupan rakyat dengan membentuk angkatan perang yang kuat. Pemikiran Machiavelli ini menegaskan bahwa negara harus mengambilalih seluruh kekuasaan yang ada pada rakyat dan sebagai konsekuensinya raja harus seialu menanamkan kepercayaan rakyat kepadanya. Dengan demikian. indikasi penguatan peran negara melalui tangan raja dalam memobilisasi kekuasaan sangat kuat.

Machiavelli tampaknya mengabaikan unsur peran rakyat yang beșar dalam dinamika kehidupan bernegara. Soal kekuasaan dalam pandangannya seolah hanya urusan penguasa. Adapun rakyat hanya menjadi pendukung penuh dari kebijakan penguasa tanpa memberi tempat yang lebih leluasa pada peranserta rakyat secara riil dalam menjalankan pemerintahan. Meskipun Machiavelli menggulirkan pemikiran tentang kekuasaan yang konstitusional. Namun sebuah: ironi kekuasaan muncul ketika raja sebagai pemegang kekuasaan justru dianjurkan untuk mempertahankannya dengan dukungan kekuatan militer atau angkatan perang. Sementara rakyat harus senantiasa patuh, taat dan merasa tergantung pada raja. Disinilah sebenarnya letak gejala sentralisasi kekuasaan pada seorang, yang dapat memicu tumbuhnya rasa tidak puas di kalangan rakyat. Disamping itu, kekuasaan yang ada pada raja cenderung memperbesar kekuasannya. Dengan mengatasnamakan negara, raja dapat bertindak sewenangwenang. Arief Budiman mengatakan bahwa kekuasaan kepentingan umum dapat memaksakan kehendaknya melawan kehendak-kehendak pribadi atau kelompok masyarakat yang lebih kecil. ${ }^{27}$

Machiavelli tampak berada pada pernyataan di atas. Sebab, raja atas nama negara diperbolehkan bertindak dengan

\footnotetext{
${ }^{27} \mathrm{lbid} ., \mathrm{HIm} .5$.
} 
kekerasan fisik. Bahkan kekejaman seorang raja dapat dibenarkan selama itu dilakukan untuk kemuliaan rakyat dan negarà. Tétapi,. sampai dimanakah tindakian raja menggunakan kekerasan dapat ditóleransi? Padahal jika negara mempunyai tujuan untuk membuat rakyat aman, damai, makmur dan sejahtera tentunya cara-cara represif seorang raja harus dihindari. Hal ini perlu dilakukan oleh seorang penguasa yang benar-benar menghayati arti penting kehidupan bernegara yang harmonis. Memang bukan hal yang mudah untuk mewujudkan harmoni dalam menjalankan kekuasaan negara. Sebab, konflik-konflik yang berkembang di tengah masyarakat sangat kompleks. Demikian pula konflik-konflik di tingkat elit kekuasaan dalam struktur kelembagaan negara. Namun demikian, banyaknya konflik ini bukan berarti harus dihadapi dengan kekuatan angkatan perang atau militer yang cenderung represif, melainkan harus dihadapi dengan manajemen konflik secara persuasif, meskipun memakan waktu yang agak lama. Dengan cara seperti ini, harmoni kekuasaan dapat menemukan waktu yang agak lama. Dengan cara seperti ini, harmoni kekuasaan dapat menemukan muaranya, sehingga tujuan negara bukan semata-mata untuk mempertahankan kekuasaan, tetapi untuk mengelola kehidupan bernegara secara harmonis dan mampu memberi kedamaian di hati rakyatnya., Negara juga bukan alat penguasa untuk mencapai tujuan-tujuan pribadinya, melainkan sebuah wadah dimana rakyat merasa memiliki tanggung jawab untuk mempertahankannya dan menghindarkannya dari penguasa yang sewenang-wenang.

Pemikir yang sejajar dengan Machiavelli adalah Shang Yang, karena pandangannya tentang tujuan negara hampir mirip dengan Machiavelli. ${ }^{28} \mathrm{Apabila}$ orang menginginkan negara yang kuat dan berkuasa mutlak, maka ia harus membuat rakyatnya lemah dan miskin. Sebaliknya, jika orang hendak membuat rakyatnya kuat dan makmur, maka ia harus menjadikan negaranya lemah. Tujuan negara menurut Shang Yang adalah untuk membentuk kekuasaan. Oleh karena itu harus didukung oleh tentara yang kuat. sederhana dan sanggup menghadapi segala bahaya. Kesamaan antara Machiavelli dan Shang Yang terletak pada sifat kekuasaan yang harus dimiliki oleh negara. Perbedaannya adalah pada konsep Machiavelli, di balik tujuan negara kekuasaan ada tujuan lain, yaitu untuk menjaga kehormatan dan kebahagiaan. Sedangkan pada konsep Shang Yang, tujuan negara adalah kekuasaan untuk kekuasaan itu sendiri.

\section{Simpulan}

Machiavelli berbicara tentang substansi kekuasaan, tetapi tidak menggagas kembali tentang konsep kekuasaan negara, yang barangkali pernah ia pelajari dari tokoh-tokoh besar yang diakuinya memberi kontribusi besar dalam melahirkan karyanya. the Prince. Machiavelli mendobrak pemikiran tradisional tentang kekuasaan yang berlaku pada masanya, yaitu legitimasi religius-otoritas

${ }^{23}$ Moh. Kusnardi dan Bintan R Saragih. 1988. IImu Negara. Gaya Media. Jakarta. 
gereja yang dominan atas negara, tetapi alasan mengapa ia mendobraknya hanya dapat dipahami bahwa kekuasaan negara yang dijalankan oleh lembaga-lembaga religius dan raja merupakan perpanjangan tangannya yang telah melahirkan kehancuran dan ketidakadilan.

Sikap Machiavelli ini berimbas pada tujuan negara. Kekuasaan sebagai substansi dari negara dan ada pada tangan seorang raja harus dipertahankan sedemikian rupa, sehingga kekuasaan itu tidak hilang, dengan dibentuknya angkatan perang yang kuat. Negara merupakan alat bagi raja untuk mempertahankan kekuasaannya. Dalam kontek kekinian, ide Machiavelli tanpa sadar memudar, walaupun di beberapa negara tampay menguat dengan kekuatan militer dalam struktur kekuasaan negara.

Terlepas dari polemik yang sering mewarnai diskursus tantang pemikiran Machiavelli, agaknya menjadi sebuah keharusan bagi penguasa untuk memiliki basis moral yang agak kuat agar ia menjalankan kekuasaan secara bijak. Disamping itu, penguasa harus pula memahami etika politik agar ia mampu mewujudkan kekuasaan yang berwajah humanis atau kata Fran Magnis Suseno, dapat membantu usaha pengejawantahan ideologi negara yang luhur di dalam realitas politik yang nyata. Hal ini dapat direfleksikan pada apa yang menjadi inti keadilan sosial, apa dasar etis kerakyatan, dan bagaimana kekuasaan harus ditangani supaya sesuai dengan martabat kemanusiaan. ${ }^{29}$ Soal etika ini tampak hilang dari pemikiran Machiavelli. $\square$

\section{Daftar Pustaka}

A. Rahman Zainudin. 1992. Kekuasaan Negara. Pemikiran Politik Ibnu Khaldun. Jakarta: Gramedia Pustaka Utama.

Anthony Giddens dan David Held. Pendekatan

Klasik dan Kontemporer mengenai

Kelompok Kekuasaan dan Konflik.

Rajawali Press. Jakarta

Arief Budiman. 1996.Teori Negara, Negara,

Kekuasaan dan Ideologi. Gramedia. Jakarta.

Departemen Agama Republik Indonesia. 1989. Al-Qur'an dan Terjemahannya. Jaya Sakti. Surabaya.

F. Isjwara. 1987. Pengantar IImu Politik. Bandung.

Fran Magnis Suseno. 1986. Kuasa dan Moral. Gramedia. Jakarta.

, 1988. Etika Politik, Prinsip-prinsip Moral Dasar Kenegaraan Modern. 'Gramedia. Jakarta.

Hamzah Ya'cub. 1984. Filsafat Ketuhanan. Al-Maarif. Bandung.

Kirdi Dipoyudo. 1989. Tugas Pokok Negara dalam Memajukan Kesejahteraan Sosial. Analisis CSIS.

M. Sastrapratedja dan Franz M. Parera. Sang Penguasa, Surat-surat Kenegaraan untuk Umat Lorenzo De Medici. Gramedia. Jakarta

${ }^{29}$ Franz Magnis Suseno. 1988. Etika Politik, Prinsip-prinsip Moral Dasar Kenegaraan Modern. Gramedia. Jakarta. HIm. 7. 
Miriam Budiarjo. 1991. Aneka Pemikiran Muhammad Tahir Azhary. 1992. Negara tentang Kekuasaan dan Wibawa. Pustaka Sinar Harapa. Jakarta.

Demokrasi di Indonesia, Demokrasi Parlementer dan Demokrasi Pancasila. Gramedia. Jakarta

Moh. Kusnardi dan Bintan R. Saragih. 1988. IImu Negara. Gaya Media. Jakarta.

Hukum: Suatu Studi tentang Prinsip-Prinsipnya, Dilihat dari Segi Hukum Islam, Implementasinya pada Periode Negara Madinah dan Masa Kini. Bulan Bintang. Jakarta.

W.J.S. Poerwodarminto. 1976. Kamus Besar Bahasa Indonesia. Departemen Pendidikan dan Kebudayaan dan Balai Pustaka. Jakarta. 